arise from adventitious buds upon old parts of the rhizome. Possibly Helminthostachys or its ancestors branched more copiously, and Farmer's adventitious buds are due to the fact that this latent capability may still be stimulated into action under certain conditions. The fact that these buds are most frequently found upon almost decorticated fragments of rhizome appears to give colour to this suggestion.

It may also be suggested that they represent glandular organs of some kind; but, at the present day, the cells surrounding them give no particular evidence of a glandular nature.

D. T. GWYNNE-VAUGHAN.

GLasGow.

\title{
ON SECONDARY THICKENING IN ANGIOPTERIS
} FVECTA.-For some time past Professor Farmer and the writer have been engaged upon an investigation into the structure of certain Marattiaceae. Various interesting features have come to light, amongst which is secondary thickening in Angiopteris evecta.

As is well known the steles of this plant are concentric in structure, the xylem being surrounded by the phloem. Both these tissues are arranged in an irregular manner, and between them there may often be seen elements exhibiting a marked radial arrangement, exactly presenting the appearance usually associated with that of a cambium. This cambium does not by any means surround the xylem, but is of local occurrence. There can be no doubt that the tissue in question owes its presence to post-embryonic merismatic activity, in fact to the existence of a cambium, though restricted to localized areas.

Additional evidence is afforded by the fact that on the inner side of this tissue semi-lignified elements with protoplasmic contents are often formed.

The only other view that could be held regarding this formative tissue is that its occurrence is due to the retention of the arrangement of primary meristem. It is, however, extremely doubtful if such a tissue would retain its characteristics for so long a time, for the best cases of secondary tracheides, accompanied by a cambium, were seen in the lower and older regions of the plants.

Secondarily formed tracheides have also been seen in the petioles, but not in the roots.

It may also be mentioned that outside the stele there is evidence of a tentative cambial activity. The latter is again irregular in its 
distribution, but of more frequent occurrence than the intrastelar secondary thickening described above. In appearance it may be compared to the secondary activity seen in the cortex of Isoëtes.

These points, with other matter not mentioned here, will be fully dealt with in a joint paper to be published shortly.

T. G. HILL.

Royal College of Science, London.

NOTE ON SOME GRAFTING EXPERIMENTS.-The following results are the outcome of a series of experiments to test the possibility of obtaining improved varieties of cultivated plants by employing the process of grafting

The experiments of Daniel seem to show conclusively that the stock and scion mutually affect one another, and that, in some cases at all events, the changes so induced become hereditary '. So far my experiments have not been carried on for a sufficient time to reach this stage, but as they confirm several other points brought out by Daniel, and introduce new ones, they are of interest.

The most successful grafts were obtained by using seedling plants with from three to six leaves both for stock and scion. In the majority of cases tongue-grafting was used, and the scion fixed in position with a strip of thin gutta-percha wound round twice, and fastened with a ring of lead wire. Such a bandage is readily thrown off by the plant as the root or stem grows. If the operation is carried out in sunny weather, shading for three or four days is almost essential, and the leaf surface should be reduced to check transpiration.

One of the easiest plants to experiment with is the Beet (Beta vulgaris), as one can rely on almost every graft being successful.

The varieties used have been Sutton's Mammoth Long Red, Sutton's Yellow Globe, Sutton's Tankard, the Kleinwanzlebener sugar-beet, and the crimson beet. These are readily distinguished by their leaves, petioles, colour, and shape of the roots. In every case $(42$ plants) the boundary line between stock and scion was sharply marked; the white of the sugar-beet, for instance, did not gradually pass over into the crimson of the Mammoth Red-so affording a striking demonstration of the indiffusibility of the coloured cell-sap.

1 Daniel, Ann. d. Sci. Nat., I898, p. r. 


\section{$2 \mathrm{BHL}$ Biodiversity Heritage Library}

Hill, T. G. 1902. "On secondary thickening in Angiopteris evecta." Annals of botany 16, 173-174. https://doi.org/10.1093/oxfordjournals.aob.a088866.

View This Item Online: https://www.biodiversitylibrary.org/item/233980

DOI: https://doi.org/10.1093/oxfordjournals.aob.a088866

Permalink: https://www.biodiversitylibrary.org/partpdf/318670

\section{Holding Institution}

Smithsonian Libraries

\section{Sponsored by}

Biodiversity Heritage Library

\section{Copyright \& Reuse}

Copyright Status: Not in copyright. The BHL knows of no copyright restrictions on this item.

This document was created from content at the Biodiversity Heritage Library, the world's largest open access digital library for biodiversity literature and archives. Visit BHL at https://www.biodiversitylibrary.org. 